\title{
The Performance of Village Secretary Subsequent to His Appointment as Civil Servant: A Study on the Policy Implementation of Government Regulation Number 45 of 2007 in Indonesia
}

\author{
Kusworo Kusworo \\ Institut Pemerintahan Dalam Negeri \\ Cilandak, Jakarta, Indonesia \\ kusworo@ipdn.ac.id
}

\begin{abstract}
This study examines, analyzes, and describes the performance of village secretaries in Indonesia after their appointment as civil servants. The study uses descriptive approach with qualitative method. The data analysis techniques are data selection, reduction, presentation, and verification as well as deriving conclusion. The results of this study indicate that the performance of the village secretaries is generally quite fair; yet in terms of discipline, competence, and working relations with other village apparatuses, the condition has not been harmonious. There are several factors affecting the performance of the village secretary in providing services, namely a) Personality of the village secretary, particularly his quality, capability and capacity, b). Motivation, work ethics, attendance, and task design, particularly regarding the motivation to occupy the position as village secretary. Work ethics, in this case, is the discipline, loyalty, and ability/competence in carrying out the task; c). Support, especially institutional support such as training and development, facilities and infrastructure, technology, performance and management standards and personnel (coworkers) in their working environment; $d$ ) Management of career hiring and sustainability such as recruitment process; psychological relationship between village head and village secretary, social resentment of village apparatus towards the appointment of Village Secretary as civil servant; appointment, transfer, echeloning and dismissal mechanisms of village secretary (Sekdes) with civil servant background; and Sekdes career guidance mechanism with civil servants background.
\end{abstract}

Keyword: Village secretary; Civil servant; Policy implementation; Government regulation.

\section{Introduction}

Rapid institutional changes in villages prompt their human resources (apparatus) to work according to the aimed target. Therefore, village apparatus must work optimally since human resources are no longer perceived as one of production factors, a notion held by classic management theories which treat human beings as machines [1]. Today, however, a village apparatus is treated as human capital, and such circumstance follows the account of modern management views. The difference between the two notions leads to different treatments to human resources [2]. The first idea puts its human resources in a position synonymous with production management, finance, and marketing, and this certainly is not apt to human nature; its dignity as a human being is not only a source but also an executor who keeps an institution running and becomes the motor directing an organization [3]. 
Similar to other government apparatus, nowadays it is not sufficient for a village apparatus to merely serve the people. One must have the innovation to develop his or her village in order to adapt with institutional changes so that the village may be able to compete with other communities. The role of a government apparatus is not only as a facilitator and service provider, but also a "dynamic creator" (the party who creates dynamics) and an entrepreneur [4].

As the consequences of village institutional restructuring, in other words, a village apparatus needs to be sharp in facing and utilizing every challenge and opportunity. Intending to achieve a desired condition, professionalism of village governance apparatus is an undelay able necessity [5]. The need of human resources who are tough in facing village institutional change is triggered not only by internal factors but also external factors. In terms of internal factor, village apparatuses are contemporarily required to have certain skills and knowledge such as jointly formulating village regulations with Village Representative Council (BPD), managing village economy, administering village governance, and other tasks within the scope of performance of the institution and personnel. Villagers' demand for satisfactory services is something village government needs to quickly respond. In line with the institutional change of village government and organizational paradigm, the notion of human resources also undergoes some changes. Future organizations shall be Learning Organizations that provide opportunities to every employee/apparatus to constantly learn and solve problems together. What the organization needs to do is continually preparing its human resources [6].

In modern context, every organization needs to have the role and contribute to the achievement of organizational objectives. According to Senge [7], in his famous book The Fifth Discipline, in order to face changes, an organization needs to do revitalization and change each of its members' or organization's mindsets to master five pre-required disciplines. These are 1) Personal mastery, which is the ability to constantly and patiently improves one's vision in order to be objective in perceiving reality by focusing one's energy on strategic elements; 2) System of thinking, which is the ability to have a dynamic foundation of thinking for reality and its interrelated process as a whole, avoiding the trap of certainty, or looking at an issue linearly and symptomatically; 3) Mental model, which is possessing a work structure and basic assumptions in perceiving the reality, enabling one to act quickly; 4) Building shared version, which is the commitment to purely comprehend common vision for the future without coercions; 5) Team learning, which is the ability and motivation to learn adaptively, generatively, and continuously. These 5 disciplines need to be comprehensively integrated, developed, and enlivened by each organization member in order to be implemented in daily practices.

The government regulation concerning village secretary appointment into a civil servant has logical consequences, so that village government can have a high performance in serving and developing the village. Due to the application of Law No. 32/2004, specifically on the section stipulating village secretary position to be chosen from a civil servant as stated in article 202, paragraph (3), the government has issued Regional Regulation No. 45/2007, stipulating the Procedure of Village Secretary Appointment into a Civil Servant. A village Secretary is a village apparatus whose task is to help the Head of the Village in terms of establishing orderly government administration and development altogether with the public service and empowerment.

This research focuses on village secretary performance, subsequent to his appointment into a civil servant, with the locus in the villages of Gudang, Cinanjung, and Cijambu, Subdistrict of Tanjungsari. The selection of the villages considers the aspect of being the nearest, furthest villages from the Subdistrict, and the village with the most population. The composition of villages in Tanjungsari Subdistrict is based on the population density and the distance to the Subdistrict capital as illustrated in the following table: 
Table 1. Village Area, Demography, and Orbitation

\begin{tabular}{|c|c|c|c|c|c|c|c|}
\hline \multirow[t]{2}{*}{ No } & \multirow{2}{*}{$\begin{array}{l}\text { Village } \\
\text { Name }\end{array}$} & \multirow{2}{*}{$\begin{array}{c}\text { Area } \\
\left(\mathbf{K m}^{2}\right)\end{array}$} & \multirow{2}{*}{$\begin{array}{c}\text { Number } \\
\text { of } \\
\text { Families }\end{array}$} & \multicolumn{2}{|c|}{$\begin{array}{l}\text { Population Sum } \\
\text { (Individual) }\end{array}$} & \multirow{2}{*}{$\begin{array}{c}\text { Population } \\
\text { Sum }\end{array}$} & \multirow{2}{*}{$\begin{array}{c}\text { Distance } \\
\text { (Km) }\end{array}$} \\
\hline & & & & Male & Female & & \\
\hline 1 & Tanjungsari & 0.65 & 1,557 & 3,069 & 2,856 & 5,925 & 19 \\
\hline 2 & Jatisari & 81.6 & 1,616 & 2,718 & 2,832 & 5,550 & 18 \\
\hline 3 & Gudang & 1.655 & 1,739 & 2,839 & 2,789 & 5,628 & 17 \\
\hline 4 & Margaluyu & 1.50 & 1,556 & 2,512 & 2,596 & 5,108 & 18 \\
\hline 5 & Kadakajaya & 342.6 & 1,360 & 1,906 & 1,880 & 3,786 & 25 \\
\hline 6 & Pasigaran & 2.84 & 1,099 & 1,585 & 1,604 & 3,189 & 20 \\
\hline 7 & Cijambu & 1.398 & 1,224 & 1,994 & 1,967 & 3,961 & 27 \\
\hline 8 & Kutamandiri & 1.86 & 2,029 & 3,966 & 3,900 & 7,866 & 19 \\
\hline 9 & Cinanjung & 3.73 & 2,781 & 4,627 & 4,542 & 9,169 & 21 \\
\hline 10 & Raharja & 3.676 & 1,897 & 3,346 & 3,114 & 6,460 & 21 \\
\hline 11 & Margajaya & 2.259 & 2,678 & 4,681 & 4,121 & 8,802 & 21 \\
\hline \multirow[t]{2}{*}{12} & Gunungmanik & 2.46 & 2,085 & 3,990 & 3,791 & 7,781 & 18 \\
\hline & TOTAL & 34.62 & 21,621 & & & 73,225 & 244 \\
\hline 2. & & & & 37,233 & 35,992 & & \\
\hline
\end{tabular}

Source: Tanjungsari Subdistrict Profile Database, 2011

The table above shows that Cinanjung village with its 9,169 inhabitants is the most densely populated. In fact, the village's population density even surpasses the average population density in Tanjungsari subdistrict. Meanwhile, Cijambu village is one with the furthest distance to the capital of the subdistrict. On the other hand, Gudang village is the nearest. The village secretaries within the three villages have been appointed into civil servants, and in average, their education is on the level of Junior High School.

As an illustration, Tanjungsari Subdistrict of Sumedang District consists of 12 villages, in which, having implemented the Government Regulation No. 45 of 2007, there had been 12 village secretaries appointed into Civil Servants by 2008. Based on the aforementioned background and problems, the writer is then inclined to investigate the issue of "The Performance of Village Secretary Subsequent to His Appointment as Civil Servant: A Study on the Policy Implementation of Government Regulation Number 45 of 2007 in Gudang, Cijambu, and Cinanjung Villages, Tanjungsari Subdistrict, Sumedang District”. Hence, the problems discussed are as follows: 1) The level of education of a village secretary will affect his work performance; 2) There is no clarity on the pattern of a village secretary's career path; 3) As the average village secretaries appointed as civil servants have entered the period of retirement, reaching 50 years old and above, the orientations for performance improvements become ineffective and not optimum; 4) Performance assessment of the village secretary should be through DP3 (Work Performance Assessment List), since DP3 is a performance assessment tool for civil servant; 5) The biased pattern of relation between a village secretary and the head of the village leads to a condition where the village head halfheartedly give instruction to his secretary due to his rank and status; 6) There has been no direct contribution to orderly village government administration from the appointment of village secretary into civil servants; and 7) As civil servants, village secretaries are not receiving allowance from the regional budgets; thus lessens the performance of a village secretary from being maximum.

Based on the problem identification, the questions of the study are as follows: 1) How do village secretaries in the villages of Gudang, Cinanjung, and Cijambu in Tanjugsari Subdistrict, Sumedang District, perform after being appointed as civil servants? 2) Which factors are influential to the performance of village secretaries in delivering service to the people of the village? and 3) What form of regulation needs to be made to support the village secretary improve his performance? 
This research consists of six parts. The first part is the introduction, explaining the background and the identification of problems. The second part covers literature reviews, and theoretical frameworks as the foundation of the study. The third part explains the methods of the study. The fourth part is the result of the study. The fifth part contains analyses and discussions on the results in terms of the established theoretical frameworks. Lastly, the sixth part describes the conclusion of the study.

\section{Literature Review}

\subsection{Employee Performances}

Employee performance will give contribution to the achievement of institutional goals. Therefore, every institution (including the government) needs to do periodical performance assessment on its employees or members to receive accurate and precise inputs for creating regulations in the context of performance improvements in the future [8]. Work assessment system needs to provide at least two things, namely clear directions and opportunities for employees to participate in determining target and standard of performance. The three main factors, according to Mathis and Jackson [9], influencing how individuals work are as follows:

$$
\text { Performance }=\text { Ability } \times \text { Effort } \times \text { Support }
$$

a. Ability

This part consists of an employee's talents, passion, and personality.

b. Effort

Efforts consist of motivation, work ethics, attendance, and task planning.

c. Support

Organizational support consists of training and development, equipments and technologies, work standard, management, and colleagues.

\subsection{Policy Implementation}

Policy implementation is a crucial step in the process of creating public policy. A policy needs to be implemented in order to achieve the desired impact and objectives [10]. Policy implementation is principally a way to make a policy achieve its goals. Furthermore, Winarno in [10] affirms that in general, policy implementation is a step of policy process, right after the establishment of laws. Implementation is largely considered as law implementation in which various actors, organizations, procedures, and techniques work together to execute a policy in order to achieve its objectives and run the programs [11].

\subsection{Government Regulation No 45 Year 2007}

Unsatisfactory service of village apparatus' performance has become a public discourse, for instance, there are village offices that serve people only half the usual work hours; it takes a long time to process people's paperwork; many village apparatus are absent during working hours. Nonetheless, the government wishes to improve the performance of village government administrative services. Thus, professional apparatus for organizing the administration of village government are required [12].

Article 202 of Law No. 32 Year 2004 on Regional Government establishes a term that a Village Secretary fulfilling requirements in accordance to the law shall be appointed by degrees a civil servant. Accordingly, the government then publishes the Government 
Regulation No. 45 Year 2007 on the Requirements and Procedures of Village Secretary Appointment to Become Civil Servants.

\subsection{Theoretical Framework}

Based on the aforementioned explanations, the theoretical framework can be illustrated as follows:

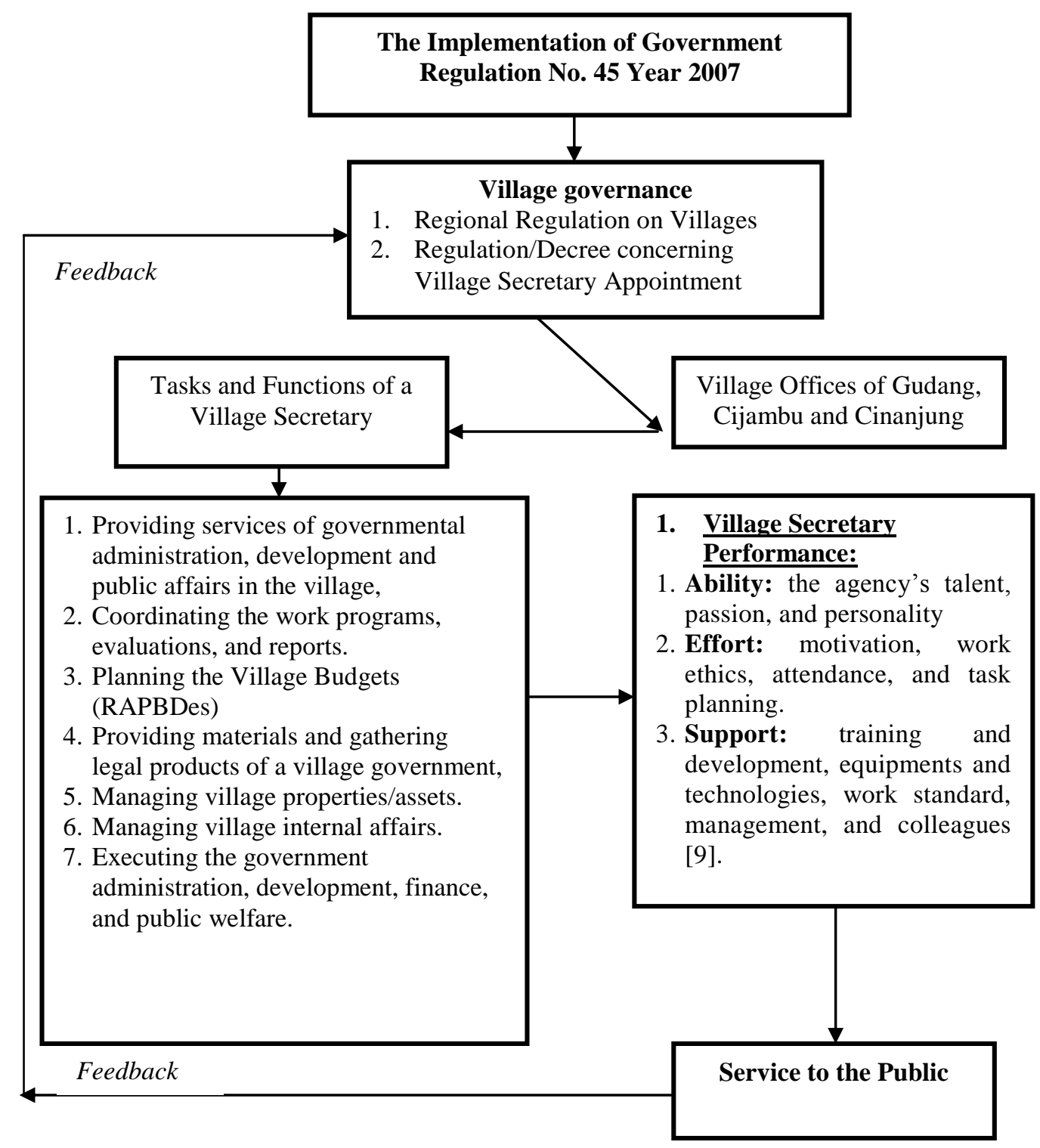

Figure 1. Theoretical Frameworks

\section{Methodology}

\subsection{Research Design}

This study is a descriptive investigation with qualitative approach. Sugiyono [13] defines such method as one "used to examine the status of a group of human beings, object, situation, and condition of a thinking system or class of events systematically, 
factually, and accurately concerning facts and relationships among the investigated phenomena".

Accordingly, qualitative study can be defined to have the following characteristics [14]: (1) Performed in a natural situation (as opposed to experiments), directly sourced from the data with the researcher as the key instrument; (2) Having more descriptive nature. The gathered data are rather in the form of words or pictures than numbers; (3) Emphasizing more on the process rather than the products or outcome; (4) Analyzing the data inductively; and (5) Stressing more on the meaning (beneath the surface of the observed data).

This study was conducted in Gudang, Cijambu, and Cinanjung villages, Tanjungsari Subdistrict, Sumedang District, West Java Province. The research itself was conducted between July and November 2011.

\subsection{Data Source}

The sources of data used in this research are 1) Person, capable to provide the data in the form of spoken answers through interviews or written answers; 2) Place, displaying features of immobile (a room, equipments, manifestation of objects) and mobile (activities, performance, etc.) states; and 3) Paper, conveying signs of letters, numbers, pictures, or other symbols, as well as tables, legislations, or other references related to the study. In addition, informants and key persons in the interviews are

Table 3.1 Informant List

\begin{tabular}{|c|l|l|}
\hline 1. & Head of Tanjungsari Subdistrict (key person) & 1 person \\
\hline 2. & Head of the villages (key person) & 3 persons \\
\hline 3. & Village Secretary (informants) & 3 persons \\
\hline 4. & Village Apparatus (informants) & 3 persons \\
\hline 5. & Heads of Neighborhood and Community Association (informants) & 6 persons \\
\hline 6. & BPD members (informants) & 3 persons \\
\hline \multicolumn{2}{|c}{ Total } & 19 persons \\
\hline
\end{tabular}

There are 15 (fifteen) respondents for this research, and 4 key persons in total.

\section{Data Analysis Method}

The technique of data analysis used in this research is a qualitative data analysis procedure, which can generally be described through the following:

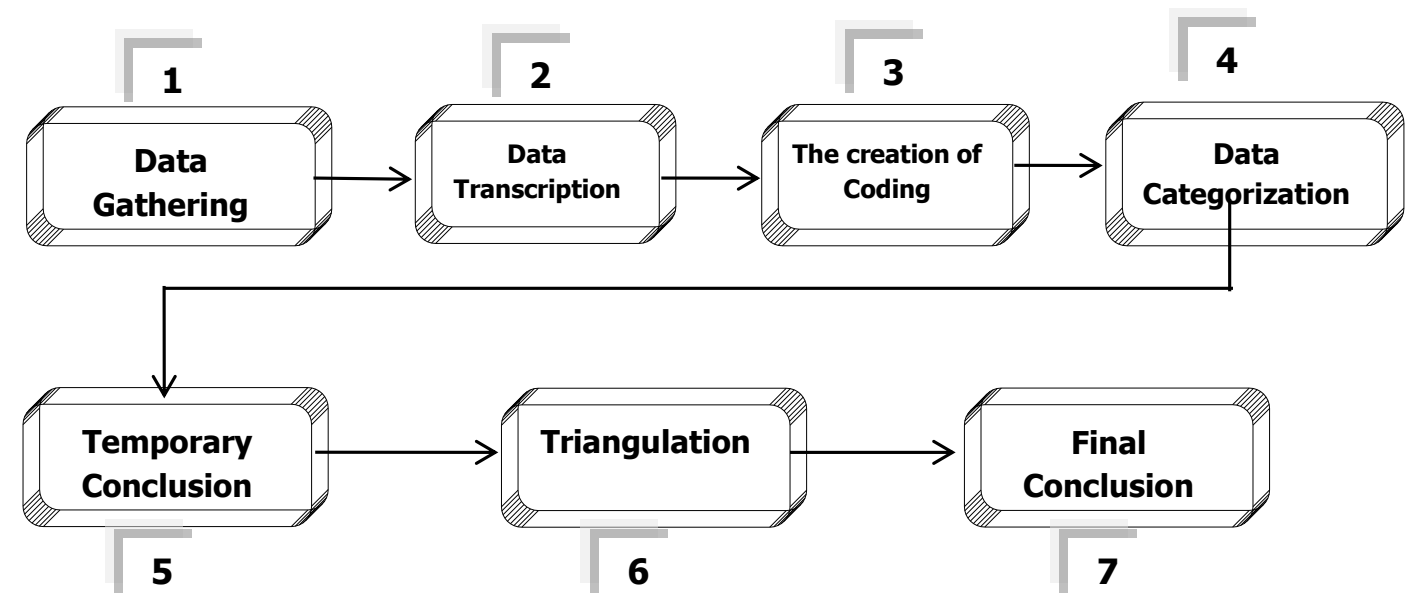

Figure 2. Data Analysis Process [15] 
Further explanation on the steps of data analysis in this research [15] is as follows: (1) Step 1: Gathering data by using the planned techniques; (2) Step 2: Raw Data obtained from the interview is transcribed into written form while the result of documentation is transferred to written notes; (3) Step 3: Results of data transcription is then given codes or special notes on important aspects related to the research questions; (4) Step 4: In order to make comprehension of the coded data easier, categorization is conducted so that data can be simplified into specific categories according to the needs; (5) Step 5: Categorized data is then analyzed specifically in order to establish a temporary conclusion; (6) Step 6: In order to obtain a valid result, triangulation process between data analysis techniques and between data sources is performed in order to draw a conclusion as answers to proposed questions; (7) Step 7: Making the final conclusion.

\section{Results of the Study}

The appointment of a village secretary into a civil servant is stipulated by legislation since it is considered a strategic position for village government; hence village secretary is expected to be the engine that drives the village government. Village secretary is an apparatus who helps the Village Head to establish orderly governmental administration and development, and provide public services and empowerment. The mandate of Government Regulation clarifies the tasks of a village secretary in doing his functions as a village apparatus.

In the interview, the Head of Tanjungsari Subdistrict said, "Sekdes (village secretary) as a civil servant has been mandated by the law; the objective of which is to make administration, development, public services and empowerment in the village level improved. Of twelve villages in Tanjungsari Subdistrict, the entire village secretaries have been appointed into PNS (civil servant). This means the performance of Sekdes as a village apparatus should be better than before the appointment to PNS." Furthermore, he said, "Measuring the quality of Sekdes' performance can be seen from how administrative matters are conducted before and after the existence of village secretary as a PNS, for instance whether the services are better or not, particularly in terms of village correspondence and paperwork, village profile, finished developments, etc."

The appointment of village secretary as a civil servant certainly has positive and negative impacts for the execution of governance in the level of village, both internal and external impacts felt by villagers. In another part of the interview, the Head of Tanjungsari Subdistrict (Camat) said, "The positive impact if the Sekdes appointed as PNS has already had competence and capability is he shall be capable in managing the administration of village government. On the other hand, if the Sekdes does not have competence and capability, there will absolutely be negative impacts since he shall have difficulties in organizing the administrations in the village level."

In another chance, the head of Cinanjung village argued that, "the [central or regional] government actually has a good intention of appointing a Sekdes into a PNS. However, in the field, sometimes when a Sekdes has already been a civil servant, the performance does not improve and in fact further declines." Furthermore, he said that, "when examined from the structure, the hierarchal pattern of a Sekdes is beneath the village head, who is in charge of village division heads. Nonetheless, a Sekdes is appointed by the Regent".

The performance of village secretary in Cinanjung Village is measured from his ability, support, and effort. Based on the interview, one of the heads of Community Association (RW) assessed that the Sekdes has been fair in terms of ability and personality: he has high motivation in working. It can be proven by his punctuality and task execution (which is neat). Nevertheless, the Sekdes still needs to be equipped with skills in using information technologies. Meanwhile, in the interview, the head of Community Association (RW) in Cijambu village said, 


\begin{abstract}
"our village secretary is now in a comfortable position; apart from being appointed as PNS, he will also have pensions. However, now with the status as PNS, his work performance should be better than before he is appointed as PNS. The condition in our village, when you ask us to comment on the Sekdes, well... just as I said. Actually the Sekdes on duty here has already been experienced in taking care of the village, so actually he already knows the condition and he can work well. Hence, it does not need to learn first. What matters is he must be honest and wholehearted in serving the people. Well his performance is quite fair."
\end{abstract}

Furthermore, the people of Cijambu village said in the interview that: "in this village [Cijambu], Sekdes' performance is actually fair. However, his discipline is still unsatisfactory since there are always cases in which the Sekdes is absent or coming not according to the working hours (although it is not always the case). Also, now that he has become a PNS he sometimes does not want to hear what his colleagues suggest."

Basically, a village secretary is a village apparatus whose task is to aid the village head establish an orderly governance administration, development, public service and empowerment. Therefore, to execute a good village governance and development, the role of a Village Secretary in managing the village governance administration is central and required, especially in taking care of the financial administration, as well as other village administration in general according to the applicable law. Considering the significant role of a Sekdes, the government has made a policy of appointing a village secretary into a civil servant. This must be perceived as the government's effort to improve the quality of governance system in Indonesia in general, and the execution of village government in particular.

\title{
5. Analyses and Discussions
}

\subsection{Work Performance of Village Secretary Subsequent to His Appointment as Civil Servant}

According to the interviews, it can be argued that the Government of Sumedang District should appoint Sekdes who pays attention to his competence and capability. In doing so, both the positive and negative impacts should be considered. The hierarchy of village government in Tanjungsari Subdistrict is, in general, similar to other villages. What differs is that the number of division heads in each particular village is adjusted to the needs of the people. Similar case can also be found in the structure of BPD, which resembles other villages.

When examined from his main objectives and roles, the task of a village secretary is actually not that easy, considering the tasks of giving governance administrative services, development and civil services in a village, coordination of work planning creation, executing evaluation and reports, planning the Village's Regional Budget (RAPBDes), providing the materials and gathering the law products of a village governance, managing a village's wealth/asset, taking care of a village's chores, and doing the governance administration, development, finance, and welfare to the public. Difficult duties and roles of a secretary demands sufficient knowledge and skills of a village secretary.

This notion is then emphasized by Cijambu Village Head, who confers with Hamlet heads in Cijambu village in saying that their village secretary has already been experienced in taking care of the village's governmental administration. It means that the Village Secretary only needs to continue his works according to his main duties and role. In my opinion, it is a good thing that a village secretary has become a civil servant. Such state gives him or her a higher condition and status, which leads to higher motivation in working with a better performance. 
Furthermore, the condition of village governance in Gudang, the village secretary has actually been working for a long time in Gudang village office. However, his education from STM makes the works on administration hindered as the competence is insufficient so that he needs to adjust to his responsibilities.

In general, the village secretaries in the three villages of Cinanjung, Cijambu, and Gudang are still incompetent in managing the village governance as nowadays, the execution of village governance is demanded to be according to the real government administration management in showing the capability of doing the task and responsibilities of improving the public services accountably.

The regulation on Sekdes appointment into PNS is also intended for creating orderly village governmental administration. With a Sekdes having a PNS background, it is expected that the village could change into a more conducive state so that the execution of village governance can be more effective, efficient and directed with its development and people empowerment enhanced.

With further examination, the central government's regulation in appointing Sekdes into a civil servant prompts undesired negative impacts. This phenomenon further influences the pace of village government and public service.

\subsection{Factors Contributing to a Village Secretary's Performance in Providing Public Services}

The work of a village secretary to fulfill his tasks is influenced by various internal and external factors of institution or organization. As a civil servant, it is necessary for a village secretary to put forward dedication and public service, putting aside political goals which benefit personal or group's agenda. Analyzing the condition in the field, there are several factors contributing to a village secretary's work performance and public services: 1) The personality of Sekdes. This involves Sekdes' quality, capability, and capacity in carrying out his roles; 2) Motivation, work ethic, attendance, and work planning. This involves what drives a person to become a village secretary. Work ethics involves discipline, loyalty, and competence in doing the assignments; 3) Support. This involves institutional support for Sekdes himself, including training and development, tools and equipments, technologies, work standard, management, or personnel (colleagues/other village apparatus) in the work environment; and 4) Management/process of appointment and career path such as selection process, psychological relationship between the village's head and secretary, social resentment from other village apparatus towards Sekdes' appointment as civil servant, recruitment mechanism, transfer process, echelonering, dismissal of Sekdes with PNS background, and the mechanism of a PNS-appointed Sekdes' career training.

The factors above will influence the performance of a village secretary in carrying out his duties and roles. Therefore, a Sekdes is demanded not only to have competence/skills but also to receive supports and to have pleasant personality.

\subsection{Necessary Policy to Improve Village Secretary's Work Performance}

The main philosophy of a government's task is to serve public needs. The various needs of the people are then accommodated and aggregated in the process of governance in order to produce different goods and services which are then formulated into a policy [16]. Related to this, the government has two main functions, namely the primary function (services) and secondary function (empowerment). The primary function of a government is to provide unprivatized public services, including defense and security, civil services, and bureaucracy. The secondary function of a government is to provide public needs and demands of goods and services which they cannot fulfill by themselves due to their weak and powerless condition, such as the provision of infrastructures and facilities. Considering such functions, the government is obliged to fulfill its responsibility 
according to public demands and needs, as a form of services to create independent communities. This goes as well for the government in the lowest level, which is village government. The importance of more concrete attention for public service prompts the government to take this matter as one of the main issues of governance implementation. Furthermore, weak discipline and low work performance of apparatuses represent the fact that most civil servants lack of competence and professionalism. This condition also shows that still there are various serious problems the government needs to face in terms of human resource empowerment. These problems include insufficient quality, education, training, and skills of the apparatuses to achieve the target of Regional Government. Additionally, uncertain career path is also another problem with different specific issues such as formation system; recruitment, promotion and mutation mechanism; and the system of reward and punishment.

In terms of performance, in order to improve the quality of a village secretary in providing better public services, the Government needs to take strategies that involves taking into account regulations concerning Sekdes candidate selection, training and supervision, career patterns of a Sekdes, salary and remuneration, Sekdes performance assessment, relationship patterns with village head and other apparatuses, as well as system of accountability and appointment of village secretary as a PNS.

\section{Conclusion and Recommendation}

According to the discussion, three conclusions can be drawn: (1) First, the work performance of village secretary in Cinanjung, Cijambu, and Gudang villages of Tanjungsari Subdistrict is generally quite fair. However, the secretaries' discipline, competence, and work relation with other village apparatuses still need to be improved; (2) Second, several factors that influence the work performance of a village secretary in serving people are: a) the personality of Sekdes, especially in terms of his quality, capability, and capacity; b) Motivation, work ethics, attendance and work planning. Village secretary's motivation, work ethics, discipline, loyalty, and competence should also be examined; c) Support, especially institutional support in forms of training and development, facilities, technologies, work standard, management, other personnel (colleagues/village apparatuses) in the surrounding work environment; and d) Management/appointment process and career path such as selection process, psychological relationship between the village's head and secretary, resentment from other village apparatuses to the Sekdes' appointment as civil servant, mechanisms of recruitment, mutation, echeloneering, and dismissal of a PNS-Appointed Sekdes, as well as career path supervision of a PNS-Appointed Sekdes; (3) Third, to improve village secretary's performance, the government needs to make policies improving the selection process of a Sekdes candidate, providing training and supervision programs, enhancing patterns of Sekdes' career path, providing salary and remuneration, Sekdes performance assessment, improving Sekdes relationship patterns with the village head and other apparatuses, and advancing the system of accountability and appointment as a civil servant.

There are several suggestions that can be proposed: (1) First, there needs to be supervision, training, and performance assessment of village secretary, so that he may carry out the duties and roles of giving public service and empowering in a more efficient way; (2) Second, in terms of appointment, there needs to be concerns and consideration on factors contributing to the improvement of performance of a village secretary. This means that it is not sufficient to only consider administrative requirements. The contributing factors in the second point of the conclusion needs to be considered as well; (3) Third, there needs to be a policy formulation to enhance the performance of a village secretary in the future. The formulation can be done through a) the policy insisting the clarity of Sekdes' career pattern and work relation with the village head and other 
apparatuses; b) the policy on taking Pamongpraja to fulfill the position of Sekdes, i.e. alumni of IPDN (Institute of Public Administration); c) policy concerning the selection and administrative requirement system for the position of Sekdes. This needs to have clarity and specific criteria, considering the dimensions of education, echeloneering, and work competence; and d) Policy changes concerning the appointment of a village secretary, i.e. Government Regulation No. 45 Year 2007 on Requirements and Procedures for the Appointment of Village Secretary into Civil Servant.

\section{References}

[1] Antlöv, H. (2003). Village government and rural development in Indonesia: The new democratic framework. Bulletin of Indonesian Economic Studies, 39(2), 193-214.

[2] Antlöv, H. (2000, July). Village Governance in Indonesia-Past, Present and Future Challenges. In PERCIK Conference "Dynamics of Local Politics in Indonesia," Yogyakarta.

[3] Kernaghan, K. (2009). Moving towards integrated public governance: Improving service delivery through community engagement. International Review of Administrative Sciences, 75(2), 239-254.

[4] Hadi, T., \& Purnama, L. (1996). Beberapa penelitian dalam Upaya Peningkatan dan Pendayagunaan Sumberdaya Manusia Aparatur Negara: Tinjauan Aspek Kelembagaan, Ketatalaksanaan, Sumberdaya Manusia dan Mekanisme Pengawasan Aparatur. Samarinda: Forum Komunikasi Pascasarjana Pemda Kalimantan Barat.

[5] Martin, S., \& Smith, P. C. (2005). Multiple public service performance indicators: Toward an integrated statistical approach. Journal of public administration research and theory, 15(4), 599-613.

[6] Joshi, A., \& Moore, M. (2004). Institutionalized co-production: unorthodox public service delivery in challenging environments. Journal of Development Studies, 40(4), 31-49.

[7] Senge, P. M. (2009). The Fifth Discipline: The Art \& Practice of the Learning Organization. New York: Doubleday.

[8] Perry, J. L., Hondeghem, A., \& Wise, L. R. (2010). Revisiting the motivational bases of public service: Twenty years of research and an agenda for the future. Public Administration Review, 70(5), 681-690.

[9] Mathis, R., \& Jackson, W. (2006). Human Resources Development. (TrackMBA, translator) Jakarta: Prestasi Pustaka.

[10] Winarno, B. (2008). Kebijakan Publik : Teori dan Proses. Yogyakarta: Media Pressindo.

[11] Aarons, G. A., Hurlburt, M., \& McCue-Horwitz, S. (2011). Advancing a conceptual model of evidence-based practice implementation in public service sectors. Administration and Policy in Mental Health and Mental Health Services Research, 38(1), 4-23.

[12] Zhu, Y.-c., Tang, J.-l., \& Lieu, C.-m. (2010). Evaluation on Rural Public Service Efficiency Based on DEA in China [J]. Soft Science, 3, 37-43.

[13] Sugiyono. (1997). Metode Penelitian Administrasi. Bandung: Alfabeta.

[14] Sugiyono. (2010). Metode Penelitian: Kuantitatif, Kualitatif dan R\&D. Bandung: Alfabeta.

[15] Dwijowijoto, R. N. (2003). Kebijakan Publik: Formulasi, Implementasi, dan Evaluasi. Jakarta: Elex Media Komputindo.

[16] Reddick, C. G., \& Turner, M. (2012). Channel choice and public service delivery in Canada: Comparing e-government to traditional service delivery. Government Information Quarterly, 29(1), 111 . 
International Journal of $u-$ and $e^{-}$Service, Science and Technology Vol.10, No.8 (2017) 